\title{
PENGARUH CRYOTHERAPY DAN ORALCARE STANDAR YANG DIGUNAKAN RS TERHADAP DERAJAT ORAL MUCOSITISPADA ANAK LEUKEMIA
}

\section{THE INFLUENCE OF CRYOTHERAPY AND ORALCARE STANDARD USED BY THE HOSPITAL TO THE DEGREE OF ORAL MUCOSITIS IN LEUKEMIA CHILDREN}

\author{
Dina Carolina ${ }^{1}$, Nyimas Heny Purwanti ${ }^{2,}$ Titi Sulastri $^{3}$ \\ Mahasiswa Fakultas Ilmu Keperawatan Universitas Muhammadiyah,Jakarta,Indonesia \\ Dosen Fakultas Ilmu Keperawatan Universitas Muhammadiyah,Jakarta,Indonesia \\ ${ }^{3}$ PoltekesKemenkes III Jakarta, Indonesia \\ Email: dinakanza.dc@gmail.com
}

\begin{abstract}
Abstrac : The Influence Of Cryotherapy And Oral careStandard Used by The Hospital To the Degreeof Oral Mucositis In Leukemia Children. Leukemia is the number one most common cancer in children. Management to eradicate leukemia cancer cells one of which is with chemotherapy. Chemotherapy is the administration of a group of drugs that are cytotoxic, whose side effects can cause oral mucositis. Giving cryotherapy is felt necessary to reduce and prevent the degree of oral mucositis in children. Cryotherapy is the administration of ice chips before, shortly and after chemotherapy for about 70 minutes. This research was conducted to see the effect of cryotherapy and standard oral care on the degree of oral mucositis. This study uses Quasi experimental with a non equivalent control group design before after design. The sampling technique used was purposive sampling with 74 respondents. Tests conducted were paired t tests and independent $t$ tests. The results showed that there was an effect of the administration of cryotherapy and oral care standard hospitaly on the intervention and control groups with $(\mathrm{p}=0,000)$. Cryotherapy can be used as one of the atraumatic care interventions of children during chemotherapy. Keywords: Leukemia, Oral mucostis, Cryotherapy + oral care
\end{abstract}

\begin{abstract}
Abstrak : Pengaruh Cryotherapy dan Oralcare Standar yang digunakan Rs Terhadap Derajat Oral mucositis pada anak dengan Leukemia.

Leukemia merupakan urutan kanker nomer satu yang banyak ditemui pada anak. Penatalaksanaan untuk memberantas sel kanker leukemia salah satunya adalah dengan kemoterapi. Kemoterapi merupakan pemberian segolongan obat-obatan yang bersifat sitotoksik, yang efek sampingnya dapat menyebabkan oral mucositis. Pemberian cryotherapy dirasakan perlu untuk menurunkan dan mencegah derajat oral mucositis pada anak. Cryotherapy adalah pemberian es keping sebelum, sesaat dan setelah dilakukan kemoterapi selama kurang lebih 70 menit. Penelitian ini dilakukan untuk melihat pengaruh cryotherapy dan oral care standar terhadap derajat oral mucositis. Penelitian ini menggunakan Quasi experimen dengan rancangan non equivalent control group before after design. Tehnik sampling yang digunakan adalah purposive sampling dengan 74 responden. Uji yang dilakukan adalah uji $t$ paired dan independent $t$ tes. Hasil menunjukan adanya pengaruh pemberian cryotherapi dan oral care standar RS terhadap kelompok intervensi dan kontrol dengan $(p=0,000)$. Cryotherapy dapat dijadikan sebagai salah satu intervensi atraumatic care anak selama menjalani kemoterapi. Kata Kunci : Leukemia, Oral mucostis, Cryotherapy+oral care
\end{abstract}

\section{PENDAHULUAN}

Kasus kanker pada anak telah meningkat sekitar $13 \%$ secara global dalam dua dekade terakhir. Setiap tahun terdapat 18,1 juta kasus baru anak di dunia terdiagnosis kanker, dan diperkirakan 9,6 juta diantaranya meninggal dunia. Angka kematian kanker pada anak mencapai $50-60 \%$ karena umumnya penderita datang terlambat atau sudah dalam keadaan stadium lanjut akibat gejala kanker yang sulit di deteksi terlebih pada anak-anak (WHO, 2018).

Di negara berkembang yang berpenghasilan rendah dan menengah, menurut Union for International Cancer Control (UICC) menyatakan setiap tahunnya terdapat sekitar 
176.000 anak yang terdiagnosis kanker. Sementara itu di Indonesia terdapat sekitar 11.000 penyakit kanker pada anak setiap tahunnya, dan terdapat sekitar 650 kasus kanker anak di Jakarta (Kemenkes RI, 2015). Berdasarkan (Riskesdas, 2013) tercatat jenis kanker yang paling banyak diderita oleh anak di Indonesia yaitu leukemia dan retinablastoma (Kanker bola mata). Leukemia merupakan kanker darah yang paling banyak ditemukan pada kasus anak- anak. leukemia terbagi menjadi dua yaitu leukemia limfoblastik akut (LLA) dan leukemia mielositik akut (acute myelogenous leukemia (AML), Diperkirakan 3-4 kasus dari 100.000 anak mengalami leukemia. Leukemia yang sering terjadi pada anak adalah leukemia limfoblastik akut (LLA) (Hockenberry\& Wilson, 2013).

Penanganan kanker pada anak bertujuan agar dapat mengendalikan jumlah dan penyebaran sel-sel kanker, penanganan kanker meliputi kemoterapi, terapi biologi, terapi radiasi, transplatasi sumsum tulang, transplatasi sel darah perifer (peripheal blood stem cell), dan oral cryotherapy. Kemoterapi adalah pemberian segolongan obat-obatan yang bersifat sitotoxic dan kemoterapi merupakan treatment primer yang digunakan untuk mengatasi kanker. Terdapat berbagai macam jenis obat kemoterapi yang diberikan dengan suatu protokol tertentu disesuaikan dengan jenis kanker yang dialami oleh anak (Hockenberry dan Wilson, 2013).

Kemoterapi merupakan salah satu terapi yang memperlihatkan efektifitas yang tinggi pada kanker (NCI, 2009).Mekanisme kerja obat kemoterapi yang sangat kuat untuk membunuh sel kanker juga bepengaruh pada sel-sel sehat terutama sel yang pembelahannya bersifat cepat seperti sel folikel rambut, sum-sum tulang belakang, kulit, dan mukosa. Sehingga obat kemoterapi akan menimbulkan beberapa efek samping pada anak diantaranya adalah terjadinya oral mukositis, yang dapat menyebakan anak mengalami kurang nafsu makan. Bila gangguan ini tidak ditangani lebih lanjut maka akan terjadi resiko tinggi pemenuhan nutrisi pada anak yang nantinya akan menjadi penurunan kualitas hidup anak penderita kanker (Gibson \&Soanes, 2008).

Di RS banyak anak menolak untuk diberikan Chlorhexidine 0,2\% dan nystatinkarena rasanya yang kurang enak. Perawat juga kesulitan memberikan Chlorhexidine 0,2\%, Nacl0,9\%atau iodine pada anak yang berusia dibawah tiga tahun karena sifatnya yang tidak boleh tertelan. Peneliti sampai saat ini terus mencari beberapa alternatif obat dalam menangani oral mucositis yang murah, efektif, bahan mudah didapat dan mudah diberikan pada anak. Menurut laporan dari pedoman ESMO working group, oralcryoterapy 30 menit dianjurkan untuk pencegahan oral mucositis pada pasien yang menerima bolus 5 kemoterapi FU (II, A) dan 20-30 menit oralcryotrapy disarankan untuk mengurangi oralmucositis pasien yang diobati dengan dosis bolus edratrexate (IV, B) (Hedryani, 2012).Menurut Cancer Care Nova Stovia, (2008) Oral Cryotherapy merupakan pemberian Es pada pasien anak yang mengalami Oralmucositis sebelum di lakukan kemoterapi selama 5 mnt, sewaktu kemoterapi selama $30 \mathrm{mnt}$, dan setelah kemoterapi selama $35 \mathrm{mnt}$.

\section{METODE}

Desain penelitian menggunakan Quasi Experimental dengan pendekatan nonequivalent control group before after design yaitu penelitian yang memberikan perlakuan atau eksperimen pada dua atau lebih grup, grup tersebut akan diobservasi sebelum dan sesudah perlakuan (Darma ,2015). Penelitian ini mengunakan nonequivalent control group dengan sampel 74 responden yang terdiri dari dua kelompok, yaitu kelompok intervensi 37 responden dan control 37 responden. Instrument yang di gunakan mengunakan OAG sebanyak 8 pertanyaan dan lembar Observasi. Instrument pada penelitian ini memiliki nilai validitas dari tiap soal kuesioner memiliki nilai koefisien validitas lebih dari $\mathrm{r}$ tabel dan reabilitas 0,910 lebih dari $r$ tabel 0,444 kemudian penelitian ini telah dinyatakan lolos kaji etik berdasarkan surat no. 079/KEKP/V/2019 setelah dinyatakan valid peneliti melakukan pengukuran derajat oral mucositissebelum di lakukan implementasi pemberian cryotherapy dan oral care standar RS dan mengukur kembali setelah di berikan implementasi, hal tersebut dilakukan selama 3hari dan dimonitoring derajat oral mucositisnya. Dan untuk kelompok control pemberian hanya diberikan oral care standar RS yaitu mengunakan nicostatin dan clorinatau obat kumur.

\section{HASIL}

Hasil penelitian didapatkan data dari distribusi karakteristik respondenUsia, Jenis Kelamin, Jenis obat kemoterapi usia secara umum 7-12 tahun intervensi 35(94,6\%), kontrol $30(81,1 \%)$. Jenis kelamin umumnya laki-laki $21(56,8 \%)$ dan $22(59,5 \%)$, Jenis obat $24(64,9 \%)$ dan $22(59,5 \%)$. 
Tabel 1: Distribusi Karakteristik Responden Berdasarkan Usia, Jenis Kelamin, dan Jenis Obat RS Dharmais, Tahun 2019

\begin{tabular}{|c|c|c|c|c|c|c|}
\hline $\begin{array}{c}\text { Varia } \\
\text { bel }\end{array}$ & $\begin{array}{c}\text { Kelom } \\
\text { pok }\end{array}$ & $\begin{array}{l}\text { Pengu } \\
\text { kuran }\end{array}$ & Mean & $S d$ & $\mathrm{Se}$ & $\begin{array}{c}P \\
\text { Val } \\
\text { ue }\end{array}$ \\
\hline \multirow{5}{*}{$\begin{array}{l}\text { Pre - } \\
\text { Post } \\
\text { Test } \\
\text { Cryot } \\
\text { herap } \\
y\end{array}$} & \multirow[t]{3}{*}{$\begin{array}{c}\text { Interv } \\
\text { ensi }\end{array}$} & Pre & $\begin{array}{c}13,7 \\
8\end{array}$ & 2,31 & 0,38 & $\begin{array}{c}0,0 \\
01\end{array}$ \\
\hline & & & & & 0,43 & \\
\hline & & Post & $\begin{array}{c}11,7 \\
8\end{array}$ & 2,61 & & \\
\hline & \multirow[t]{2}{*}{$\begin{array}{l}\text { Kontr } \\
\text { ol }\end{array}$} & Pre & $\begin{array}{l}13,3 \\
8 \\
\end{array}$ & 2,73 & 0,44 & $\begin{array}{l}0,0 \\
38\end{array}$ \\
\hline & & Post & $\begin{array}{c}12,0 \\
0\end{array}$ & 2,87 & 0,47 & \\
\hline
\end{tabular}

Tabel 2: Distribusi derajat oral mucositis anak dengan leukemia yang menjalani kemoterapi sebelum dan sesudah Cryotherapy dan Oral care

\begin{tabular}{|c|c|c|}
\hline \multirow[t]{2}{*}{ Variabel } & $\begin{array}{c}\text { KelompokIntervens } \\
\mathrm{i} \\
(\mathrm{n}=37)\end{array}$ & $\begin{array}{c}\text { KelompokKontro } \\
1 \\
(n=37)\end{array}$ \\
\hline & f $\quad(\%)$ & f $\quad(\%)$ \\
\hline $\begin{array}{l}\text { Usia } \\
\text { 4-6 Tahun } \\
\text { 7-12 Tahun }\end{array}$ & $\begin{array}{cr}2 & 5,4 \\
35 & 94,6\end{array}$ & $\begin{array}{ll}7 & 18,9 \\
30 & 81,1\end{array}$ \\
\hline $\begin{array}{l}\text { JenisKelamin } \\
\text { 1. Laki-Laki } \\
\text { 2.Perempuan }\end{array}$ & $\begin{array}{ll}21 & 56,8 \\
16 & 43,2\end{array}$ & $\begin{array}{ll}22 & 59,5 \\
15 & 40,5\end{array}$ \\
\hline $\begin{array}{l}\text { JenisObatKem } \\
\text { o } \\
\text { 1.Dosis Tinggi } \\
\quad \text { MTX }\end{array}$ & $24 \quad 64,9$ & 2259,5 \\
\hline $\begin{array}{c}\text { 2.Dosis Sedang } \\
\text { Vencristin }\end{array}$ & $13 \quad 35,1$ & 1540,5 \\
\hline $\begin{array}{l}\text { Uji ya } \\
\text { untuk meng } \\
\text { derajat oral } \\
\text { dilakukan in } \\
\text { dilakukan unt } \\
\text { yang paling } \\
\text { mucositis. B } \\
\text { kelompok in } \\
\text { dapatkan hasi } \\
\text { mucositis pa } \\
\text { dilakukan p } \\
\text { setelah diberil }\end{array}$ & $\begin{array}{l}\text { g dilakukan ada } \\
\text { tahui apakah te } \\
\text { mucositis sebel } \\
\text { tervensi dan } \\
\text { k mengetahui ke } \\
\text { besar penurun } \\
\text { rdasarkan uji } \\
\text { ervensi sebelum } \\
\text { umumnya rata } \\
\text { a kelompok in } \\
\text { lakuan yaitu } \\
\text { an perlakuan men }\end{array}$ & $\begin{array}{l}\text { ah Paired t tes } \\
\text { dapat perbedaan } \\
\mathrm{m} \text { dan setelah } \\
\text { it independent } \\
\text { ompok manakah } \\
\text { derajat oral } \\
\text { njutan antara } \\
\text { lan setelah di } \\
\text { rata derajat oral } \\
\text { rvensi sebelum } \\
3,78 \text { sedangkan } \\
\text { adi } 11,84 \text {. }\end{array}$ \\
\hline
\end{tabular}

Hal ini menunjukan bahwa rata-rata oral mucositis setelah dilakukan perlakuan mengalami penurunan rata-rata 1,94. Pada data rata-rata derajat oral mucositis kelompok kontrol sebelum dilakukan perlakuan yaitu 13,38 sedangkan setelah diberikan perlakuan menjadi 12,00 . Hal ini menunjukan bahwa rata-rata oral mucositis setelah dilakukan pengukuran mengalami penurunan rata-rata 1,38 . Hasil rata-rata derajat oral mucositis sebelum dan setelah dilakukan intervensi pada kelompok 1 dan 2 mendapatkan hasil kelompok $1 \alpha=0,001$ dan kelompok 2 $\alpha=0,038$ artinya terdapat penurunan derajat oral mucosistis yang signifikan di kedua kelompok, walaupun terdapat penurunan dari kedua keloompok namun kelompok intervensi lebih signifikan terlihat mendekati $\alpha=0,000$. Terlihat dari hasil uji anova untuk pengaruh usia, jenis kelamin dan jenis obat kemoterapi tidak ada pengaruh yang menyebabkan terjadinya oral mucositis, dengan hasil $\alpha<0,05$.

\section{PEMBAHASAN}

\section{Usia}

Menurut Lailatul Fitria, (2018) yang mengemukakan pendapat bahwa anak yang menderita kanker terbanyak pada rentang usia 611 tahun yaitu sebesar $67 \%$. Hal ini sesuai dari pendapat Bowden\& Greenberg, (2010) yang mengatakan bahwa kanker pada anak biasanya tidak terdeteksi. Kurangnya kesadaran orang tua untuk memeriksakan tanda gejala awal yang timbul dari penyakit anaknya juga termasuk faktor pemberat dari penyakit kanker itu sendiri, sehingga saat ditemukan penyakit tersebut biasanya sudah terlambat atau usia anak sudah besar sehingga prognosis kesembuhan semakin kecil.

Disamping itu salah satu penyebab timbulnya leukemia yang lain adalah faktor gentik. Faktor ini jugalah yang menyebabkan kelainan bawaan sejak lahir juga memperbesar potensi anak untuk menderita leukemia, misalnya pada anak dengan down syndrome.

\section{Jenis Kelamin}

Hasil penelitian menunjukkan bahwa jenis kelamin yang paling banyak mengalami oral mucositis adalah laki-laki yaitu sebanyak 22 anak (59,5\%). Penelitian ditunjang dari Mulatsih Sri, 2010 yang mengatakan bahwa persentase pasien laki-laki dan perempuan masing-masing 18 dan 15, karena menurut peneliti insidensi lakilaki lebih banyak dibanding perempuan karena relaps sering menyerang pada susunan sistem syaraf dan testis. Prognosis yang buruk pada laki- 
laki dibanding perempuan karena pada anak lakilaki lebih sering dijumpai T-ALL angka leukosit tinggi serta lebih sering mengalami testicular relapse.

\section{Jenis Obat Kemoterapi}

Obat MTX ini sangat sering diberikan pada pasien kanker darah dan nasofaring. Anak yang mendapat terapi dengan dosis lebih besar. terhadap pengobatan akan lebih rentan mengalami mucositis.Kemoterapi yang dilakukan dalam waktu yang lama, seperti pada anak yang mengalami relaps terhadap pengobatan juga meningkatkan risiko terjadinya mukositis. Selain itu pasien yang mendapat kombinasi terapi juga memiliki risiko lebiih tinggi mengalami mukositis dibandingkan dengan terapi tunggal (Cheng\&Yuen, 2014).

Hal ini sesuai dengan pendapat Cawley \& Benson, (2015) Terkait dengan faktor risiko yang berhubungan dengan terapi yang diperoleh, oral mucositis dipengaruhi oleh agen kemoterapi, dosis kemoterapi, intensitas pengulangan terapi. Agen kemoterapi yang paling sering terkait dengan mukositis adalah antimetabolit yang meliputi etoposide, $5 \mathrm{FU}$, dan Methotrexate (MTX).

\section{Pengaruh cryotherapy dan oral care standar RS terhadap derajat oral mucositis}

Hasil dari penelitian terdapat pengaruh pemberian cryoterapy dan oral care standar RS, hal ini sesuai dengan pendapat dari Wodzinski, (2016) yang menyatakanbahwapemberian cryoterapy dilakukan sebagai pencegahan terhadap kejadian mucositis setelah dilakukan kemoterapi, dari sekian banyak cara pencegahan dan penyembuhan oral mucositis hanya pemberian cryoterapy yang dinyatakan aman digunakan sehingga banyak organisasi multinational memberikan dukungan untuk penggunaan cryoterapy sebagai perawatan kanker 2014 oleh internasional society of oral oncology.
Tabel.3:Perbedaan Derajat oral mucositis sebelum dan sesudah Intervensi berdasarkan Kelompok

\begin{tabular}{|c|c|c|c|c|c|c|}
\hline $\begin{array}{c}\text { Variabe } \\
1\end{array}$ & $\begin{array}{l}\text { Perla } \\
\text { kuan }\end{array}$ & $\begin{array}{c}\text { Mea } \\
\mathrm{n}\end{array}$ & $\begin{array}{c}\text { Media } \\
\mathrm{n}\end{array}$ & SD & $\begin{array}{l}\text { Min } \\
-\mathrm{Mx}\end{array}$ & $\mathrm{n}$ \\
\hline $\begin{array}{c}\text { Derajat } \\
\text { Oral }\end{array}$ & Pre test & $\begin{array}{c}13,7 \\
8 \\
\end{array}$ & 14,00 & $\begin{array}{c}2,31 \\
1 \\
\end{array}$ & $\begin{array}{l}10- \\
18 \\
\end{array}$ & $\begin{array}{l}3 \\
7 \\
\end{array}$ \\
\hline $\begin{array}{c}\text { mucosit } \\
\text { is } \\
\text { Interve } \\
\text { nsi }\end{array}$ & Post test & $\begin{array}{c}11,8 \\
4\end{array}$ & 12,00 & $\begin{array}{l}2,64 \\
1\end{array}$ & $9-17$ & $\begin{array}{l}3 \\
7\end{array}$ \\
\hline $\begin{array}{c}\text { Derajat } \\
\text { Oral } \\
\text { mucosit }\end{array}$ & $\begin{array}{l}\text { Pre } \\
\text { test }\end{array}$ & $\begin{array}{c}13,3 \\
8\end{array}$ & 13,00 & $\begin{array}{c}2,73 \\
2\end{array}$ & $9-18$ & $\begin{array}{l}3 \\
7\end{array}$ \\
\hline $\begin{array}{c}\text { is } \\
\text { Kontrol }\end{array}$ & Post test & $\begin{array}{c}12,0 \\
0\end{array}$ & 12,00 & $\begin{array}{c}2,87 \\
7\end{array}$ & $9-17$ & 3 \\
\hline
\end{tabular}

Hasil penelitian menunjukkan bahwa ada perubahan signifikan pada kelompok intervensi nilai probabilitas ( $p$ value) $t$ independent sebesar 0,001 dan kelompok kontrol sebesar 0,038 . Nilai tersebut menunjukan bahwa $\mathrm{p}$ lebih kecil dari nilai $\alpha(0,05)$ sehingga dapat disimpulkan bahwa pada derajat kepercayaan $95 \%$ terdapat perbedaan yang signifikan antara derajat oral mucositis sebelum dan setelah interveni pada kelompok intervensi dan kontrol. Hasil Penelitian terlihat bahwa walaupun terdapat sama-sama penurunan pada kelompok intervensi dan kontrol namun penurunan derajat oral mucositis setelah di berikan intervensi cryoterapy dan Oral care standar terlihat lebih signifikan.

Hal ini sesuai dengan jurnal penelitian dari Okamoto koichi, (2019) yang mengatakan bahwa terdapat perbedaan yang membandingkan group yang tidak diberikan cryoterapy $(24,1 \%)$ dan group yang diberikan cryotherapy $(71,4 \%)$ terhadap keberhasilan dalam menurunkan skala oral mucositis.

Menurut peneliti dengan diberikan cryotherapy atau keping es membuat vasokontriksi pembuluh darah yang mengandung obat kemo ke jaringan mucosa mulut, sehingga efek dari obat kemo yang bersifat toksik dapat di cegah dan juga dapat menurunkan derajat oral mucositis dikarnakan efek dari es dapat mempercepat penyembuhan pada sel mulut. 


\section{SIMPULAN}

Teori model yang di gunakan pada penelitian ini adalah teori model dari Kolcaba (Alligod, 2013) yaitu teori "Comfort" yang terkenal dengan 3 tahapan keperawatan reli, ease, dan transcendence. Relief diartikan sebagai keadaan dimana perasaan ketidaknyamanan dapat berkurang, Ease diartikan sebagai hilangnya rasa ketidaknyamanan yang spesifik, Transcendencedidefinisikansebagaikeadaandim anaseseorang dapat kembali pulih dari rasa ketidaknyamanan jika rasa ketidaknyamanantersebuttidak bisa untuk dihindari.

Aplikasi comforttheory dalam penanganan oral mucositis akibat pemberian obat kemoterapi pada anak dapat diuraikan bahwa untuk aspek Health careneed yaitu anak memiliki kebutuhan rasa nyaman dan perhatian selama prosedur kemoterapi, dimana oral mucositis akibat efek dari kemoterapi dapat berkurang bahkan mungkin dihilangkan. Aspek Nursing Intervension yaitu terapi oral cryotherapy dan oral care standar untuk memberikan rasanyaman pada anak, dengan tujuan untuk mengurangi dan menghilangkan derajat oral mucositis akibat kemoterapi. Pemenuhan rasa nyaman yang baik pada semua aspek dengan tingkatan relief hingga transcendence akan mendorong penurunan lama hari rawat anak, penurunan kebutuhan akan tindakan medis dan peningkatan kepuasan anak dan keluarga.

Dari hasil penelitian di atas diketahui bahwa dengan penambahan pengunaan Cryotherapy dapat meningkatkan percepatan pemulihan dan juga dapat mencegah dari terjadinya oral mucositis pada anak leukemia dengan tindakan kemoterapy.

\section{SARAN}

Bagi Institusi RS, Sesuai dari kesimpulan di atas bahwa pemberian Cryoterapy dan oral care standar RS berpengaruh untuk menurunkan derajat oral mucositis, sehingga penelitian ini dapat di terapkan sebagai implementasi keperawatan di RS, adapun pihak RS dapat berkerjasama dengan bagian Gizi untuk menyediakan es keping sebelum, sesaat dan setelah dilakukan kemoterapi pada anak.

Bagi Pendidikan Keperawatan, Ilmu keperawatan dapat berkembang lebih jauh lagi disesuaikan dengan perkembangan penelitian diindustri 4.0, sehingga mampu menyesuaikan dengan zaman yang moderen

Bagi Peneliti Selanjutnya, Mengembangkan penelitian dari cryoterapy dengan memvariasikan berbagai model dan rasa untuk anak-anak.

\section{DAFTAR PUSTAKA}

Alligood, M. R., \& Tomey, A. N. (2014). Nursingtheory. Utilization \& application.Edition, ST. Louis : Mosby elsevier, Inc

Bowden, V. R., Greenberg, C. S., \& Donaldson, N. E. (2010). Children and Their Families. (2nd ed).

China: Lippincot Williams \& Wilkins

Cawley, M. M., \& Benson L.M. (2005). Current trends in managing oral mucositis. Clin $\mathrm{J}$ Oncol Nurs. 9(5), 584-592.

Ceng \& yuen. (2014). Factor influencing comfort level in head and neck neoplasm patients receiving radiotherapy,international jurnal of nurseing since, sciencedirect. 394-399

Darma Kusuma, K. (2015). Metodelogi penelitian keperawatanp panduan melaksanakan dan menerapkan hasil penelitian. Jakarta:TIM

Desen, wan Penerjemah: Japaries Willie. (2011). Buku ajar onkologi klinis. Edisi 2. Jakarta: Fakultas Kedokteran Universitas Indonesia.

Fitria laelatul, (2018). Gambaran gejala awal anak dengan limfositik akut di Rsud dr.Moewardi Jogyakarta, Skripsi program studi keperawatan fak. Muhammadiyah Surakarta.

Gibson, F. S. (2008). Cancer in children and young people. West Sussex: John Wiley \& Sons.

Heydari, Abbas., Hassan Sharifi, Roham Salek. (2012). "Effect of oral cryotehrapy on combination chemotherapy -iduced Oral mucositis: A Randomized Clinical Trial". Middle East Journal Of Cancer 2012;3 (2\&3);55-64. [internet] Diambil dihttp://search.ebscohost.com/

Hockenberry, M. J. (2013). Wong's Essentials of Pediatric Nursing (9 th Ed). St. Louis: Mosby Elsevier.

Juniman, T. P. (2018, Oktober 13). WHO kanker membunuh hampir 10 juta orang di dunia tahun ini. hal. http://www.cnnindonesia.com/gayahidup/20180913133914-255-329910/who- 
kanker-membunuh-hampir-10-juta-orangdi-dunia-tahun-ini.

Kemenkes infodatin, Pusat data dan informasi Stop Kanker, (2015) http://www.depkes.go.id/resources/down load/pusdatin/infodatin/infodatinkanker.pdf

Kemenkes. (2015, Desember). Kementerian dan kesehatan ajak masyarakat cegah dan kendalikan kanker. hal. (http://www.depkes.go.id/article/print/170 20200002/kementerian-kesehatan-ajakmasyarakat-cegah-dan-kendalikankanker.html.

Mulatsih, S., Astuti, S., \& Purwantika, Y. (2008). "Kejadian dan Tata Laksana Mukositis pada Pasien". Sari Pediatri, Vol. 10, No. 4, [internet] diambil dihttps://saripediatri.org/index.php/sari-
pediatri/article/viewFile/652/587.

National Cancer Institute. (2010). "Surveillance, epidemiology and end result (SEER"). [internet] diambil diwww.seer.cancer.gov/canque/incidence.h tml.

nuraeni. (Maret 2013). Skor mucositis pada anak dengan kanker yang menjalani kemoterapi di RSUP dr. Hasan Sadkin. Jurnal Keperawatan Soedirman (The Soedirman Journal of Nursing), Volume 8, No.1.

Riskesdas. (2013, Agustus). Kementerian Kesehatan Ajak Masyarakat Cegah Dan Kendalikan Kanker., hal. (http://www.depkes.go.id/article/print/17 020200002/kementerian-kesehatan-ajakmasyarakat-cegah-dan-kendalikankanker.html 